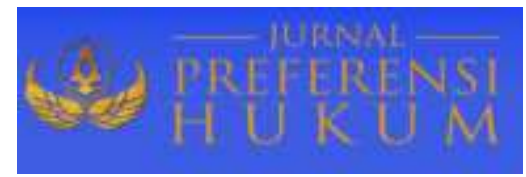

Jurnal Preferensi Hukum | ISSN: 2746-5039

Vol. 2, No. 2 - Juli 2021, Hal. 320-325| Available online at

https://www.ejournal.warmadewa.ac.id/index.php/juprehum

DOI: https://doi.org/10.22225/jph.2.2.3328.320-325

\title{
PELAKSANAAN UNDANG-UNDANG NOMOR 28 TAHON 2014 TENTANG HAK CIPTA TERKAIT PENGGANDAAN BUKU PADA USAHA FOTOKOPI CAHYA PRINTING BALI
}

\author{
Ni Luh Dwi Ega Mileniawati, Nella Hasibuan O'ieary, Desak Gde Dwi Arini \\ Fakultas Hukum, Universitas Warmadewa, Denpasar-Bali, Indonesia \\ egamileniaoo@gmail.com, nellahasibuanoleary@gmail.com, rinidesak1966@gmail.com
}

\begin{abstract}
Abstrak
Hakekat pembangunan nasional adalah pembangunan manusia seutuhnya dan pembangunan seluruh masyarakat Indonesia berdasarkan Pancasila dan Undang-undang Dasar Negara Republik Indonesia Tahun 1945. Pembangunan tidak hanya mengejar kemajuan lahiriah atau batiniah aja melainkan mengejar keselarasan, keserasian, dan keseimbangan. Tujuan dari penelitian ini untuk mengetahui Pelaksanaan Undang-Undang Nomor 28 Tahun 2014 tentang Hak Cipta terkait penggandaan buku illegal pada usaha fotokopi Cahya Printing Bali dan untuk mengetahui perlindungan hukum kepada pencipta buku terkait penggandaan buku illegal pada usaha fotokopi Cahya Printing Bali. Metode penelitian yang digunakan adalah menggunakan metode penelitian hukum empiris, yaitu melakukan pengkajian terhadap ketentuan hukum yang berlaku atau yang terjadi dalam kenyataan yang terjadi di masyarakat. Hasil penelitian mengatakan bahwa pelaksanaan Undang-undang Nomor 28 Tahun 2014 tentang hak cipta terkait penggandaan buku illegal pada usaha Fotokopi Cahya Printing Bali belum terlaksana karena kurangnya dukungan dari pihak-pihak terkait yaitu masih lemahnya penertiban dari pihak Kepolisian dan kurangnya sosialisasi. Perlindungan hukum bagi pencipta buku terkait penggandaan buku illegal pada usaha fotokopi Cahya Printing Bali dalam melindungi hak pencipta pemerintah tidak memberikan perlindungan hukum secara langsung.
\end{abstract}

Kata kunci: Pelaksanaan Hak Cipta, Perlindungan Hukum, Penggandaan Buku.

\begin{abstract}
The essence of national development is the development of the whole human being and the development of the entire Indonesian society based on Pancasila and the 1945 Constitution of the Republic of Indonesia. Development is not only pursuing physical or mental progress, but also pursuing harmony, harmony and balance. The purpose of this study is to determine the implementation of Law Number 28 of 2014 concerning Copyright related to illegal copying of books in the Cahya Printing Bali photocopy business and to find out legal protection for book creators related to illegal book duplication in the Cahya Printing Bali photocopy business. The research method used is to use the empirical legal research method, which is to study the legal provisions that apply or what happen in reality in society. The results of the study show that the implementation of Law Number 28 of 2014 concerning copyright related to illegal book duplication in the Cahya Printing Bali photocopy business has not been carried out due to lack of support from related parties, namely still weak policing and lack of socialization. Legal protection for book creators related to the copying of illegal books in the copy business of Cahya Printing Bali in protecting creators' rights, the government does not provide direct legal protection. Keywords: Implementation of Copyright, Legal Protection, Book Duplication.
\end{abstract}

\section{PENDAHULUAN}

Istilah Copyright (Hak Cipta) pertama kali dikemukakan dalam Berne Convention yang diadakan tahun 1886. Dalam Berne Convention, pengertian Hak Cipta tidak dirumuskannya dalam Pasal tersendiri namun tersirat dalam Article 2, Article 3, Article 11 dan Article 13 yang isinya diserap dalam Pasal 2 jo Pasal 10 Auteurswet 1912 (Saidin, 2004: 61). Dalam UU Hak Cipta, Indonesia merupakan negara yang menganut sistem pendaftaran deklaratif dimana sejak suatu ciptaan lahir, pencipta secara otomatis mendapatkan perlindungan atas hak-hak nya tanpa arus melalui proses pendaftaran sebelumnya. Hakhak yang dimaksud disini adalah meliputi hak ekonomi (economic rights) dan hak moral (moral rights). Hak ekonomi (economic rights) adalah hak untuk mendapatkan manfaat ekonomi atas ciptaannya 
dimana hak tersebut berupa hak untuk melakukan: penerbitan ciptaan, penggandaan ciptaan, penerjemahan ciptaan atau salinannya, pertunjukan ciptaan, pengumuman ciptaan, komunikasi ciptaan, penyewaan ciptaan. Sedangkan hak moral (moral rights) adalah hak yang melekat pada diri pencipta atau pelaku yang tidak dapat dihilangkan atau dihapus tanpa alasan apapun walau hak cipta atau hak terkait telah dialihkan. Jadi dalam Undang-Undang Hak Cipta telah jelas disebutkan bahwa hanyalah pencipta yang dapat menikmati hak-hak atas ciptaannya tersebut.

Hakikat yang berisi pembangunan dimana disebut pembangunan yang utuhnya ada bagi kita semua dimana pembangunan tersebut dilaksanakan berdasar UUD 1945 dan tentunya Pancasila. Pembangunan pada dasarnya tidak mengijinkan dan mengejar suatu hal yang maju atau hanya kepuasan batin, dimana melainkan mengejar keserasian, keseimbangan dan keselarasan. Suatu keseimbangan yang mana diwujudkan dalam hal pembangunan di setiap kehidupan yang ada pada masyarakat saat ini di Indonesia.

Pembangunan beberapa sektor fisik adalah usaha antara pemerintah dengan masyarakat, demikian dengan sektor non fisik dimana tidak lepas juga dari peran pemerintah dan masyarakat. Pembangunan yang terdapat pada sektor non fisik adalah berupa budaya dan seni sebagai media yang digunakan untuk berkarya dan berekspresi.

Seiring dengan adanya perkembangan zaman saat ini yang ditandai dengan munculnya suatu reformasi yang sangat berubah total di setiap bidang-bidangnya, salah satu contoh adalah kebebasan dalam hal berkebudayaan dan berkesenian. Hak Kekayaan Intelektual adalah suatu kekayaan yang lahir dan timbul dari intelektual kemampuan manusia. Dimana timbulnya karya dan lahir suatu kemampuan dari seseorang dengan intelektuaJ yang mana harus dijaga dan dilindungi. Dimana hal-hal tersebut lahir dari manusia dengan melalui karya, rasa dan daya yang diwujudkannya. Karya intelektual juga hadir dan lahir dengan nilai, dengan memanfaatkan perekonomian yang dimana akan menimbulkan konsepkonsep kekayaan kepada karyanya (Margono, 2014).

Undang-undang yang merupakan UU yang terakhir adalah UU No 28 Tahun 2014 tentang Hak Cipta. Dimana pemerintah Indonesia memiliki langkah-langkah untuk mengganti UU No. 19 Tahun 2002 mengenai Hak Cipta dimana bertujuan untuk melindungi hak moral pencipta, hak ekonorni dan yang terpenting adalah hak pemilik. tersebut (Yusran Isnaini, 2009 2).

Penelitian ini mengambil beberapa acuan dari penelitian sebelumnya salah satunya penelitian yang dilakukan oleh Nahfidatul Nurlaela Oktavia (2015) tentang Implementasi Undang-Undang Nomor 28 Tahun 2014 Tentang Hak Cipta Terkait Penggandaan Buku (Studi Kasus Usaha Fotokopi di Kawasan Universitas Negeri Semarang), Finna Wulandari, I Made Udiana (2017) Kegiatan Usaha Fotokopi Dalam Kaitannya Dengan Perlindungan Hukum Hak Cipta.Vina Maulani (2015) Perlindungan Hak Ekonomi Pencipta Buku Terhadap Budaya Hukum Right To Copy Dengan Mesin Fotokopi

Dari hasil pemaparan diatas peneliti menyimpulkan bahwa tujuan dari penelitian ini yakni mengetahui Pelaksanaan Undang-Undang Nomor 28 Tahun 2014 tentang Hak Cipta terkait penggandaan buku illegal pada usaha fotokopi Cahya Printing Bali dan mengetahui perlindungan hukum kepada Pencipta buku terkait penggandaan buku illegal pada usaha fotokopi Cahya Printing Bali.

\section{METODE PENELITIAN}

Penelitian pada penulisan ini memakai penelitian dengan hukum empiris, yang mana akan melakukan kajian-kajian kepada ketentuan hukum yang hadir dan nyata pada saat keadaan sekarang, atau dengan suatu penelitian yang akan diterapkan kepada keadaan yang saat ini ada dan terjadi di masyarakat yang mana dengan maksud untuk menemukan dan mengetahui fakta-fakta dan data yang akan diperlukan dan digunakan. Merupakan sebuah data yang mana dapat dengan cara langsung datang ke lapangan yang berdasar dari pihak narasumber. Dimana pengumpulan pengumpulan data yang dilakukan pada saat di lapangan dilakukan dengan wawancara langsung. Pengumpulan data yang terdapat dalam studi pustaka yang akan dilakukan dengan suatu objek penelitian. Data tersebut diperoleh dari buku-buku kepustakaan, browsing internet, peraruran perundang-undangan dan atau dengan dokumen lain. Dimana peneliti akan mencar-cari buku yang ada kaitannya dengan suatu masalah tersebut.Dalam hal ini peneliti akan melakukan observasi, wawancara dan metode dokumentasi dengan memperoleh data yang berkaitan dengan ha! atau variabel yang dimana berbentuk transkip, buku, majalah, agenda dan hal-hal 
lainnya yang berkaitan. Data-data yang didapatkan melalui sebuah peneliti dan kepustakaan tersebut akan dianalisis dengan cara interpretasi secara logis yang kemudian akan dibuat dan dikaji dengan cara kualitatif yang kemudian akan diurai dengan konsep• konsep dari literatur dan memberi argumen dengan kaitan konsep yang satu dengan konsep hukum yang lain. Yang pada akhimya hasil tersebut akan dibuat dengan cara deskriptif yaitu dengan cara menjabarkan aspek hukum yang berkaitan dan ada sangkut pautnya dengan masalh-masalah yang muncul.

\section{HASIL DAN PEMBAHASAN}

\section{Pelaksanaan Undang-Undang Nomor 28 Tahun 2014 Tentang Hak Cipta Terkait Penggandaan Buku Pada Usaha Fotokopi Cahya Printing Bau}

Sejarah berkembangnya Hak cipta (bahasa yang baik dan lazim digunakan pada saat ini untuk sebuah kata copyright) yang dimana awalnya dikenal dengan sebutan hak pengarang yang mana terjemahan dari sebuah kata yang berasal dari Belanda yaitu utrecht . Dan kemudian pada tanggal 2 oktober 1951 penggunaan kata hak pengarang dibahas pada Kongres kebudayaan Indonesia di Bandung dan mempersempit pengertian dari hak cipta. Dimana digunakan hak penulis, seakan akan pengaturan hanya mengatur hak mengenai pengarang dan akan bersangkutan dengan suatu karangan saja, sedangkan jika dilihat lebih jauh cakupannya lebih luas dari hak penulis. Karena hal tersebutlah kongres tersebut memutuskan untuk mengganti istilah kata pengarang menjadi sebuah kata Hak cipta. Yang kemudian istilah ini ada sampai sekarang dan dimana kata tersebut di perkenalkan oleh Soetan Moh Syah yang mana beliau adalah ahli bahasa. Menurutnya kata terjemahan auteurecht hak pencipta, dimana disederhanakan akan lebih mudah dan praktis menjadi sebuah kata hak cipta. Damian Edy (2014:117) Hak cipta adalah bentuk yang ada pada Hak Kekayaan lntelektual, tetapi pada dasarnya hak cipta sangat mencolok dan lebih beda dari hak kekayaan intelektual seperti hak paten yang memuat hak monopoli atas pemakaian di karena

hak cipta bukanlah hak monopoli unruk melakukan suatu hal, melainkan sebuah hak yang dibuat unruk memberi pencegahan terhadap orang lain.

Ruang lingkup hak cipta meliputi has ii pada karya-karya yang berbentuk sastra, ilmu pengetahuan dan karya seni. Hak cipta akan didapatkan langsung dimana karyanya akan diwujudkan nyata. Namun, unruk suatu kebutuhan bukti hak cipta akan memungkinkan didaftarkan pada pihak Direktorat Jenderal HKI (Riswandi, 2009:7).

Negara indonesia telah meratifikasi suatu konvensi di bidang hak cipta dengan sebutan Berne Convention pada tanggal 7 mei 1997, yang mana konsekuensinya negara Indonesia harus menjaga dan melindungi dari berbagai seluruh negara-negara rnaupun negara anggota Berne Convention, Dimana sistem pendaftarannya adalah menggunakan sistem deklaratif, karena pendaftaran tidak harus dibuat secara mutlak yang mana dalam hal tersebut suatu penciptaan dilakukan sama seperti pendaftaran. Sistem yang berlaku adalah sistem deklaratif adalah hukurnan yang diberi kepada sang pencipta atau pemilik hak pertama sehinggajika ada yang melakukan pengakuan dimana pihak tersebut memiliki hak atas suatu hak ciptaannya makan disana pencipta atau pemilik akan bisa memberi bukti dan menunjukan bahwa ialah pemegang dan pencipta atas suatu hak tersebut.

Hak cipta tersebut muncul dan timbul dengan cara otomatis setelah suatu ciptaan muncul dan lahir tanpa mengurangi suatu batas, dengan hal lain siapa yang memberi pengumuman awal ialah merupakan hak cipta yang dianggap pengumuman tersebut dari seorang pencipta dan sekaligus sebagai pemiliknya (Abdul Salimin, 2010:175).

Dimana hasil wawancara tanggal 31 desember 2020 dengan bapak I Komang Murtika memberi pernyataan bahwasannya hak cipta terkait dengan usahanya fotokopi Cahya Printing Bali, pihak toko buku-buku maupun pengarang tidak ada sebuah perjanjian tertulis mengenai hal royalty adanya penggandaan dalam benruk-benruk fotokopi.

Wawancara tersebut mengarah pada tentang penggandaan suatu buku-buku illegal, Bapak Komang Murtika menyatakan alasan suatu penggandaan buku, yaitu dengan adanya kemajuan teknologi informasi yang disamping ketersediaan jumlah buku yang ada di pasar jumlahnya sangat sedikit, kurangnya suatu kehormatan kepada Hak Cipta, dan kurangnya suatu penegak hukum yang mengenai suatu penggandaan buku-buku.

Jadi munculah permasalahan yang mana latar belakangnya adalah penggandaan buku, terutama oleh peserta didik dan pelaku pendidikan, perlu untuk di telusuri. Jika dilihat hal yang paling banyak terjadi khususnya untuk sebuah penggandaan pada tingkat pendidikan tinggi dimana karena susah unruk 
mencari literatur yang ada dipasaran. Hal tersebut berlaku untuk sebuah karya asing, dimana faktor lainnya adalah karena buku tersebut sudah tidak lagi diproduksi dan dicetak kembali, sehingga toko buku dan pengarang tidak mempunyai stok buku tersebut.

\section{Perlindungan Hukum Bagi Pencipt A Buku Terkait Penggandaan Buku Pada Usaha Fotokopi Cadya Printing Bali}

Hingga kini,jika kita pihak pemerintah telah melakukan upaya pengurangan terhadap adanya pelanggaran Hak Cipta. Dimana upaya-upaya tersebut antara lain adalah.

1. Penyesuaian dan Pembentukan Perundang-undangan

Upaya yang dapat diberikan disini adalah dalam sebuah perlindungan yaitu dengan cara disahkannya UU Hak Cipta No 28 Tahun 2014. Dimana dengan berlakunya undang-undang tersebut , Hak Cipta terdahuJu adalah suatu delik biasa sekarang dapat menjadi delik aduan dimana memudahkan pemegang dan pencipta hak cipta bisa melakukan aduannya terhadap PPNS Kementerian Hukum dan penyidik kepolisian karena suatu pelanggaran yang dilakukan.

2. Melakukan Sosialisasi

Upaya lain yang bisa dilakukan dalam perlindungan terhadap Hak Cipta dengan cara melakukan kegiatan sosialisasi dengan melalui seminar baik ditingkat kota, kabupaten dan tingkat provinsi. Sosialisasi tersebut diterapkan dengan tujuan untuk memberikan kesadaran pada masyarakat umum dimana agar mau untuk lebih bisa memberi penghargaan dan menghargai hak cipta yang dibuat oleh orang lain dengan cara yang mudah yaitu dengan cara tidak akan pernah mau melakukan suatu penggandaan buku illegal secara diam-diam tanpa seizin dari pihak yang menciptakan buku tersebut. Adanya upaya ekstemal dengan cara seminar dan sosialisasi yang bisa dilakukan kepada masyarakat umum dan mahasiswa, dimana harapannya seminar dan sosialisasi tersebut selanjutnya diberikan kepada pemilik usaha, mahasiswa, pengarang dan atau penulis suatu pemilik hak cipta sehingga kegiatannya berjalan dalam kondisi yang optimal.

Hasil wawancara yang dilakukan tanggal 31 desember 2020 dengan Putu Diah Nita Agustini menyatakan dimana perlindungan hukum bagi mereka yang menciptakan buku terkait dengan penggandaan buku yang bersifat illegal pada usaha Fotokopi Cahya Printing Bali di dalam perjanjian sebuah lisensi pada pengusaha fotokopi berhak memperbanyak hasil ciptaan dimana dengan atas izin pihak pencipta dan pihak pemilik usaha fotokopi harus mau wajib untuk membayar royalti terhadap pencipta buku. Dimana pada perjanjian lisensi [ Kadek Budi Arsana sebagai pihak pertama (Manajer Usaha Kopi) dan Syamsudin (Pencipta Buku) sebagai Pihak Kedua dalam perjanjian yang tercantum pada Pasal 4 mengenai Kompensasi yang isi perjanjiannya antara lain adalah

1) Semua biaya penggandaan atau serta mengedarkan buku tersebut disediakan dan ditanggung sepenuhnya oleh pengusaha fotokopi

2) Pencipta buku bisa mendapat dari pengusaha fotokopi

a. Biaya pembayaran OU/right yang telah dapat kesepakatan sebesar Rp

10.000.000,00 (Sepuluh Jura Rupiah) untuk buku yang diterbitkan diserahterimakan setelah perjanjian kerjasama pengadaan ditandatangani oleh kedua pihak.

b. Buku karya tersebut dari has ii pengkopian pertarna dengan curna-cuma, sebagai bukti pengkopian sebanyak 5 (Ii ma) eksemplar.

3) Pengusaha fotokopi berhak berpegangan kepada lisensi atas hak penggandaan dan hak cipta karya tulis ini hingga jangka waktu tidak terbatas.

Sebaiknya pelaku usaha fotokopi yang akan melakukan penggandaan buku untuk meminta izin dan memberitahu dari penulis atau pencipta buku dengan cara mau melakukan kerjasama antara masingmasing pihak. Dimana dengan adanya kerjasama tersebut, pemilik usaha fotokopi menghargai karya yang dibuat oleh pihak penulis atau pihak pencipta dengan cara memberi royalti sesuai dengan yang sudah disepakati di awal, sehingga penulis dan pencipta buku dengan pelaku pemilik usaha fotokopi akan bisa untuk lebih aktif dalam mempertahankan masing• masing haknya.

Hal ini akan membuat pencipta atau penulis buku memantau has ii dari karya yang telah diciptakan nya yang akan digandakan dimana juga sebaliknya pelaku usaha fotokopi harus tetap berkomunikasi baik dan selalu memberi kabar kepada penulis atau pencipta buku bahwasannya hasi I dari karya-karya yang tel ah digandakan yang didapat dari hasil fotokopi terkait adanya penggandaan buku-buku tidak membuat penulis dan pencipta buku tersebut merasa dirugikan sehingga jika dilihat malah sating menguntungkan masing-masing pihak. 


\section{SIMPULAN DAN SARAN}

\section{Simpulan}

Hasil pemaparan diatas saya simpulkan sebagai berikut:

1. Dirnana pelaksanaan UU No 28 Tahun 2014 mengenai hak cipta yang berhubungan terhadap adanya penggandaan sebuah buku illegal pada usaha Fotokopi Cahya Printing Bali dimana implementasi dan atau pelaksanaanya belum terjalan dan terlaksana karena ada kekurangan suport dari pihak yang bersangkutan terkait sangat lemah penerbitan oleh pihak pemerintah $t$ dengan adanya penggandaan buku-buku serta sangat kurang adanya bentuk sosialisasi mengenai Hak Cipta kepada masyarakat sekarang.

2. Perlindungan hukum terhadap pencipta buku mengenai penggandaan buku illegal pada pemegang fotokopi Cahya Printing Bali dilatarbelakangi dengan banyaknya penggandaan buku illegal, terpenting oleh kalangan pelaku pendidik dan anak didik, penggandaan di tingkat pendidikan tinggi adalah karena kesulitan mencari literatur tersebut di pasar. Faktor lainnya karena buku tersebut sudah tidak lagi dibuat kembali, sehingga toko dan pihak penerbit tidak mempunyai stok. Hal lain lagi sebagai penyebab munculnya tindakan penggandaan adalah karena harga buku di Indonesia masih terbilang mahal menurut ukuran kemampuan para pendidik dan anak didik. Dalam melindungi hak pencipta pemerintah tidak memberikan perlindungan hukum secara langsung. Perlindungan hukum hak cipta dibutuhkan keaktifan pencipta unruk mernpertahankan haknya. Di samping pencipta buku tidak tahu adanya penggandaan buku pada usaha fotokopi. Sebaiknya usaha fotokopi yang menggandakan buku memberitahu atau meminta izin dari pencipta atau penulis buku dengan mengadakan kerjasama antara kedua belah pihak. Dengan mengadakan kerjasama, usaha fotokopi menghargai hasil karya pencipta atau penulis buku dengan memberikan royalti sesuai kesepakatan kedua belah pihak, sehingga pencipta atau penulis buku dan usaha fotokopi lebih aktif dalam mempertahankan haknya

\section{Saran}

Dari hasil penelitian skripsi ini terdapat dua saran yaitu:

1. Seharusnya pernerintah sering melakukan penyuluhan hukum mengenai Hak Cipta kepada pemilik usaha fotokopi, agar mereka menyadari akan sangat penting Hak Cipta, dimana pelaku mau ikut serta turut aktif dalam mempersempit dan mengurangi kegiatan penggandaan suatu buku. Karena hal tersebut merugikan bagi pihak yang membuat buku-buku tersebut.

2. Pemilik usaha fotokopi diharapkan unruk tidak lagi mau menggandakan buku illegal hanya unruk memenuhi kebutuhan perekonomian saja. Tetapi mau untuk ikut berperan aktif untuk berbuat baik sesuai norma hukum perdata dan hukum pidana. Kepada masyarakat diharapkan yang masih dalam mengikuti pendidikan ataupun sudah bekerja untuk mau membeli buku-buku yang asli yang dimana kita harus bisa menghargai hasil karya-karya seseorang sebagai wujud terimakasih dan penghargaan terhadap penulis dan pencipta buku tersebut.

\section{DAFTAR PUSTAKA}

Margono. (2001). Metodologi Penelitian Hukum Kekayaan lruelekiual. Rineka Cipta.Jakarta. Damian, E. (2002). Hukum Hak Cipta. PT. Alumni Bandung.Bandung.

Riswandi, B. A. (2009). Hak Cipta di Internet : Aspek Hukum dan Permasalahannya di Indonesia (edisi 1). FH UII Press. Yogyakarta.

Salimin, A. R. (2010). Hukum. Bisnis untuk Perusahaan. Kencana Prenada Media Group.Jakarta.

Lsnaini, Y. (2009). Hak Cipta dan Tantangannya di Era Cyberspace. Ghalia Indonesia.Bogor.

Wulandari, F., \& Udiana, I. M. (2017). Kegiatan Usaha Fototkopi dalam Kaitannya dengan Perlindungan Hukum Hak Cipta. Kerta Semaya, Vol.5 No.2

Oktavia, N. N. (2015). Implementasi Undang-Undang Nomor 28 Tahun 2014 Tentang Hak Cipta Terkait Penggandaan Buku (Studi Kasus Usaha Fotokopi di Kawasan Universitas Negeri Semarang).Skripsi. Fakultas Hukum Universitas Negeri Semarang. 
Vina, M. (2015). 2015 Perlindungan Hak Ekonomi Pencipta Buku Terhadap Budaya Hukum Right to Copy Dengan Mesin Fotokopi. Skripsi. Fakultas Hukum Malang Universitas Brawijaya.

Saidin. (2004). Aspek Hukum Kekayaan Intelektual. PT. Raja Grafindo Prasada.Jakarta. Usman, R. (2003). Pilihan Penyelesaian Sengketa di Luar Pengadilan. Citra Aditya Bakti. Jakarta. 